\title{
An Analysis on the Relationship among Trust in Manager, Political Behavior and Organizational Commitment: The Case of a Sports Organization
}

\author{
Sevim Gullu ${ }^{1}$, Kadir Yildiz ${ }^{2}$ \\ ${ }^{1}$ Istanbul University-Cerrahpasa, Faculty of Sport Science, Sport Management Department, Istanbul-Turkey \\ ${ }^{2}$ Manisa Celal Bayar University, Faculty of Sport Science, Sport Management Department, Manisa-Turkey \\ Correspondence: Sevim Gullu, Istanbul University-Cerrahpasa, Faculty of Sport Science, Sport Management \\ Department, Istanbul-Turkey. E-mail: sevim.gullu@istanbul.edu.tr
}

Received: January 8, 2019

doi:10.11114/jets.v7i3.3957
Accepted: January 31, $2019 \quad$ Online Published: February 14, 2019

URL: https://doi.org/10.11114/jets.v7i3.3957

\begin{abstract}
The article aims to provide an insight into the relationship among political behavior, trust in manager and organizational commitment in sports organizations. The research is designed with a descriptive and relational survey model which is one of the qualitative research methods. The research group consists of 109 employees (48 females, 61 males) working in Erzincan Youth Services and Provincial Directorate of Sports, selected with convenience sampling method, one of the non-random sampling methods. As data collection tools, Personal Information Form, Organizational Commitment Scale, Trust in Manager Scale and Political Behavior Scale were used. SPSS 22 package program was used to analyze the data. Arithmetic mean, frequency and standard deviation were used in the statistical representations of the data. For the normality of the data, skewness and kurtosis values were taken into consideration and the data were found to have a normal distribution. Pearson correlation analysis and multiple regression analysis were used to analyze the data. The results of the study show that there is a negative relationship between the sub-dimensions of the political behavior scale and the sub-dimensions of the trust in manager scale. Similarly, as the values of the sub-dimensions of the political behavior scale increase, the organizational commitments of the participants decrease. According to the results of multiple regression analysis, the sub-dimension of cognition-based trust, one of the sub-dimensions of trust in manager scale, is an important predictor of affective commitment, which is one of the sub-dimensions of organizational commitment scale. One of the statistically significant results of multiple regression analysis is that acting two-faced sub-dimension of the political behavior scale is a significant predictor of continuance commitment, which is one of the sub-dimensions of organizational commitment scale.
\end{abstract}

Keywords: political behaviour, trust in manager, organizational commitment, organizational trust, organizational politics

\section{Introduction}

The main objective of an organization is to maintain its existence in healthy relations both within the organization and with its external environment. Strong communication within and outside the organization significantly effects employees' level of commitment to the organization. Strong employee commitment and the effectiveness of the organization in the external environment enable a robust organizational structure. Organizations should aim to bring organizational health and work life quality to an advanced level and establish the right relations with their external stakeholders. Healthy individual-individual and individual-organization relationship/ communication will ensure mutual trust within organizations and this will lead to an increase in employees' commitment. In this process, managers must undertake very important tasks. Excessive political behavior emphasizing the unwritten rules of business life can lead to decrease in employees' trust in the organization.

\subsection{Organizational Commitment}

The efficient use of human resources, which is an important element in an organization, is important for the organization to achieve its goals, to adapt to the changes and developments brought by today's conditions and to keep up with the competitive environment (Ince, 2005). An organization needs to ensure that employees are committed to the 
organization in order to get the most out of their intelligence and capabilities (Yilmaz, 2009: 477).

Organizational commitment refers to the eagerness of employees to embrace the objectives and values of their organizations, to be ready to make efforts in this direction and to continue their membership in their organizations (Ince \& Gul, 2005). As employees' organizational commitment increase, they embrace the organization's goals more easily and their eagerness to make sacrifices for their organizations increase. Thus, they fulfill their duties more effectively in the organization (Gulova \& Demirsoy, 2012). Organizational identification and internalization are also indicators of organizational commitment (Ibicioglu, 2000).

Meyer and Allen's (1991) three-component model of organizational commitment is widely adopted in studies on organizational commitment:

- Affective commitment: An employee's affective commitment implies his/her emotional attachment to the organization and eagerness to remain in the organization (Allen and Meyer, 1990). Affective commitment is influenced by organizational traits such as organizational justice and organizational policies, and personal traits such as age, gender and seniority, and work-related factors such as the business environment and the manager's approach (Meyer \& Allen, 1997). This is the most sought after and desired type of commitment for organizations. Employees with high affective commitment are usually more eager to make sacrifices for their organizations.

- Continuance Commitment: It is summarized by two types of variables, namely investments and alternatives (Meyer \& Allen, 1997) and is a kind of commitment occurring from the costs associated with an employee's leaving his/her organization (Allen \& Meyer, 1990). This is, in other words, an employee's desire to stay in the organization stemming from his investments for the organization. It has many sub-causes such as seniority, relationships with co-workers and career (Koc, 2009). This is also referred to as compliance commitment in the literature and is used to express superficial commitment to the organization. Accordingly, an employee complies with his/her organization for promotion, salary increase or similar interests (Kul \& Guclu, 2010).

- Normative commitment: In this, the employee feels a sense of obligation to stay in the organization (Allen \& Meyer, 1990). This is the least known of the three dimensions of organizational commitment (Meyer and Allen, 1997). This is the kind of commitment that is related with the concern for the inability to afford alternative costs and with the consideration of the continuation of membership in the organization as a moral necessity (Wasti, 2009).

A good management style and leadership are seen as a precondition for organizational commitment because effective leadership facilitates the use of individuals' skills and abilities for the benefit of the organization (Geri, 2010). According to Brown's (2003) study, organizational commitment increases as leaders demonstrate leadership styles that create trust, inspire a common vision, and trigger creativity. In a work environment where there is a manager who is sensitive to the needs of employees, the organizational commitment of employees increases because the employees feel themselves indebted and grateful to their managers in such a relationship (Gundogan, 2009). If managers define a common vision and are sensitive to the needs of their employees and occasionally support them, the employees will be more likely to develop a sense of respect, admiration and trust towards their employees. This, in turn, increases emotional commitment to the manager and hence to the organization. Therefore, in order to increase employees' commitment to their organizations, managers need to adopt and maintain trust-based behaviors (Demirel, 2008). On the other hand, when employees perceive injustice in the organization, they can develop negative feelings, attitudes and behavior towards their managers, co-workers and the organization and this can result in a decrease in organizational commitment (Tutar, 2007). Therefore, positive organizational justice perception will lead to increase in organizational commitment (Bagci, 2013).

At this point, communication is very important. In organizations where there is a multifaceted and open communication, employees will have the opportunity to express themselves and increase their self-confidence (Eroglu, 2011). In this way, motivation and efficiency will increase, respect for the management will increase, the authority of the management will be strengthened, and trust in the manager and the organization will increase (Boyaci, 2010).

\subsection{Trust in Manager}

Trust in its general sense means a belief in the other person that he/she will not engage in any action or hold any opinion that may be harmful to the other person (Uslu \& Ardic, 2013:315). Trust is one of the most needed feelings in interpersonal relations. A person develops a sense of trust based on many events and situations (Asunakutlu, 2002: 2). It takes time to build trust while it is too easy to lose trust (Krot \& Lewicka, 2012). Individuals want to feel a sense of trust in every aspect of their lives. Therefore, they need to feel trust in the workplace where they spend a significant amount of their time (Yilmaz \& Sunbul, 2009:174). Trust is multidimensional, it may be among co-workers or between 
an employee and a manager. It is an effective and key element: it reduces risks and operating costs, increases employee commitment and efficiency (Krot \& Lewicka, 2012). It is one of the most important components that nurture organizational health (Bell \& James, 2002:160; Coban 2007:27) and work life quality and decreases counterproductive work behaviors (Odemis, 2011:34; Sahin, 2017:6).

Trust is important within an organization because it allows employees to unite around shared values, vision and mission (Bokeoglu \& Yilmaz, 2008:225). The development of job satisfaction, organizational commitment and sense of belonging in employees depends on a corporate culture based on trust. Trust is a corporate value that can be defined as a social adhesive that holds employees together (Uslu \& Ardic, 2013:329). In organizations where a sense of trust is shared by all employees, there is a system of healthy functioning values; in other words, employees are treated in accordance with ethical principles (Teyfur et al., 2013:89).

An employee doesn't have to like his/her manager to trust him/her. Moreover, he/she does not have to agree with his/her manager. Trust in the manager is the belief that the manager's words and actions are consistent. Managers who want successful management will want to ensure employees' emotional and logical commitment. Managers who want to gain the trust of employees are expected to have personal traits such as being fair, honest and self-sacrificing. Trusting a person will lead to a commitment to that person (Akis, 2004: 391; Ozdasli \& Yucel, 2010). Therefore, managers who want to ensure the commitment of their employees must first establish a trust environment (Akis, 2004: 391). Trust-based relationships in work environments will increase the trust in manager and affective commitment (Ozturk \& Aydin, 2012: 487).

In an environment of trust, the employee will adopt productive work behaviors with a feeling that his/her manager bears in his/her mind the employee's best interests (Mayer, Davis \& Schoorman, 1995: 712; as cited in: Arslantas, 2008: 102). Consistent (Deluga, 1994:317) managers who keep their promises (Hubbell \& Chory-Assad, 2005:51), build effective communication and allow interaction ensure that their employees trust in them (as cited in: Ulker, 2008:191). Trust in a manager contributes to the development of organizational citizenship behavior, organizational commitment, job satisfaction and leader-member exchange (Bijlsma \& Van de Bunt, 2003: 639).

Trust in manager as defined by McAllister (1995:26) is examined under two dimensions in Turkish literature:

- Affect-based Trust: Grounded in reciprocated interpersonal care and concern (Ulker, 2008:195,196). Emotions and relationships are at the forefront; it focuses on the essence of the relationship between the manager or the viewer or how the viewer interprets the relationship (Arslantas, 2008: 102). Emotions and relationships are at the forefront in this type of trust and there is an emotional expectation. Benevolence, concern for the other party and generosity are the characteristics that express affect-based trust (Turgut, 2016). In the literature, it is also referred to as relationship-based trust (Arslantas, 2007: 165). Affect-based trust dimension measures the ability to share mutual ideas, emotions, challenges and problems in the workplace, and to express the manager's interest and analytical approach to problems and his / her sadness in case of inability to work (Saglam-Ari \& Tuncay, 2010).

- Cognition-based Trust: It is related to the degree of trust felt towards people under certain conditions. It expresses the beliefs of others about the credibility, honesty and loyalty of a person. For the development of trust-based relations, it is expected that reliability and loyalty coexist. The current knowledge and good reasons are the basis of the decision of trust. The individual invests emotionally in trust relationships and shows real care and interest for the good of the other and believes that such relationships are intrinsic competence and that this is the response to their sensitivity (Ulker, 2008: 195,196). Cognitive-based trust measures professional approach to work, adequacy of information on business, ability to make the right decisions, dedication to work, respect that others feel for him/her and sense of trust others develop for him/her (Saglam-Ari \& Tuncay, 2010).

\subsection{Political Behavior}

Political behavior is the process of influencing someone else's behavior in order to achieve personal goals (Aslan \& Pektas, 2017: 87) and generally occurs as a result of the efforts of the individuals in the organization to increase their interests (Cinar-Altntas, 2007). The common point of definitions of political behavior is that this behavior serves the interests of the individual, helps him/her to reach the desired results more quickly, and that it is not tolerated by organizations (Islamoglu \& Boru, 2007). Intensity of political behaviors and organizational politics which differ according to the structure of organizations, is a part of organizational life (Eryilmaz \& Gulova, 2017). The power struggles that occur in every organization and influence tactics are seen as the requirements of business life (Yuksel \& Bolat, 2016). The tendency to engage in political behavior is triggered by such factors as the limitation of resources (Akcakanat \& Uzunbacak, 2017), the desire to be ahead of others in order to reach these limited resources, the attempt to create an advantage in order to be promoted, and at least to maintain one's position within the organization. Political behaviors are not explicit; they are implicit and symbolic. How these behaviors are perceived varies according to 
individuals, organizational structure and time. Some behaviors that are innocent for some can be political for some (Eryilmaz \& Gulova, 2017). The political atmosphere within an organization is very important for shaping business attitudes such as job satisfaction, organizational commitment, work anxiety, absenteeism and labor turnover (Vigoda-Gadot, Vinarski-Peretz \& Ben-Zion, 2003). The higher employees' perception of organizational politics, the lower their perception of equality, rights and justice will be (Vigoda-Gadot, 2007). When an employee feels that he/she is deprived of some opportunities or that he/she has been treated unfairly for political reasons, a decrease arises in his/her gratefulness towards the organization and then he/she tends to react to the organization. These spontaneous attitudes and reactions can not be directly controlled by organizations. The topic that is most studied about this is organizational commitment (as cited in: Yuksel \& Bolat, 2016: 181; Vigoda, 2000).

Perception of organizational politics is positively associated with turnover intention and neglect in the workplace. In organizations where employees have a high perception of organizational politics, employees have less confidence in organization management because the balances may change in favor of those who can act politically. Organizational politics can be regarded as one of the factors that make the earnings / labor ratio of the employees unequal because they can cause unfair gains (Basar \& Varoglu, 2016).

Political behavior is examined under six sub-dimensions (Islamoglu \& Boru, 2007);

- Making concessions: In order to get a group to accept themselves or to gain love and respect in that group, the employee agrees with some ideas even though he/she normally disagrees with them.

- Acting two-faced: It is a situation in which an employee pretends to believe something that he/she does not really believe, speaks ill of other employees to show that he/she is better than them, learns the other employee's secrets with a sneaky attitude, and uses his/her secrets in favor of himself/herself.

- Ingratiation: Accordingly, an employee pleases or tries to establish good relations with his/her manager by praising him/her in order to get him/her to agree to something.

- Forming coalitions: The employee tries to suppress and influence the manager by taking the support of the other employees, in other words by cooperating with them.

- Exchange of favors: The employee forms relationships based on self-interest with the other employees; he/she reminds of the favors he/she did in the past and implicitly implies that he/she is expecting something in return.

- Inspirational appeals: The employee tries to form close relationships with the senior management, chooses his/her clothes according to their taste and makes his/her manager feel superior in his/her relationships with his/her manager.

Accordingly, this paper aims to provide an insight into the relationship among political behavior, trust in manager and organizational commitment in sports organizations.

\section{Materials and Method}

\subsection{Research Model}

The research is designed with a descriptive and relational survey model which is one of the qualitative research methods.

\subsection{Research Group}

The research group consists of 109 employees (48 females, 61 males) working in Erzincan Youth Services and Provincial Directorate of Sports in Turkey, selected with convenience sampling method, one of the non-random sampling methods.

\subsection{Data Collection Tools}

As data collection tools, Personal Information Form, Organizational Commitment Scale, Trust in Manager Scale and Political Behavior Scale were used.

- Organizational Commitment Scale: The scale was developed by Meyer and Allen (1984-1997) and adapted into Turkish by Wasti (2000). Its validity and reliability study was performed by Basol \& Yalcin in 2009. The 18-item measurement tool consists of three sub-dimensions: affective (1, 3, 5, 7, 8 and 11th items), continuance $(2,4,6,13,15$ and 16 th items) and normative $(9,10,12,14,17$ and 18 th items) commitment. It is a 5-point Likert type scale.

- Trust in Manager Scale: It is a 5-point Likert type scale. It was developed by McAllister (1995) and adapted into Turkish by Saglam-Ari (2003). This 11-item scale consists of two sub-dimensions: affect-based trust (1-5 items) and cognition-based trust (6-11 items). 
- Political Behavior Scale: It was developed by Islamoglu and Boru (2007). The version of Oruc (2015) was used in this study. It consists of 36 items and 6 sub-dimensions: making concessions (1-9 items), acting two-faced (10-19th items), ingratiation (20-24th items), forming coalitions (25-29th items), exchange of favors (30-33th items), inspirational appeals (34-36th items). It is a 5-point Likert type scale.

\subsection{Data Analysis}

SPSS 22 package program was used to analyse the data. Arithmetic mean, frequency and standard deviation were used in the statistical representations of the data. For the normality of the data, skewness and kurtosis values were taken into consideration and the data were found to have a normal distribution. Pearson correlation analysis and multiple regression analysis were used to analyse the data.

\section{Findings}

This part of the research includes the results and interpretation of the data.

Table 1. Demographic profile of the participants

\begin{tabular}{|c|c|c|c|c|c|}
\hline \multicolumn{2}{|l|}{ Variables } & Number & $\%$ & $\mathbf{X}$ & SD \\
\hline Age & & & & 33.87 & 8.42 \\
\hline The years worked for the organization & & & & 5.71 & 7.11 \\
\hline \multirow{2}{*}{ Average hours worked daily } & & & & 7.89 & 1.21 \\
\hline & Female & 48 & 44.0 & & \\
\hline \multirow[t]{2}{*}{ Gender } & Male & 61 & 56.0 & & \\
\hline & Total & 109 & 100.0 & & \\
\hline \multirow{4}{*}{ Marital Status } & Single & 46 & 42.2 & & \\
\hline & Married & 63 & 57.8 & & \\
\hline & Primary school & 5 & 4.6 & & \\
\hline & High school & 20 & 18.3 & & \\
\hline \multirow[t]{4}{*}{ Educational Background } & Associate degree & 20 & 18.3 & & \\
\hline & Undergraduate degree & 62 & 56.9 & & \\
\hline & Master & 2 & 1.8 & & \\
\hline & Permanent & 43 & 39.4 & & \\
\hline \multirow[t]{6}{*}{ Type of employment } & Contractual & 55 & 50.5 & & \\
\hline & Part time & 11 & 10.1 & & \\
\hline & $\begin{array}{l}\text { Senior manager (general manager / } \\
\text { assistant general manager / director) }\end{array}$ & 6 & 5.5 & & \\
\hline & Middle management (Chief / Supervisor) & 10 & 9.2 & & \\
\hline & Expert / Assistant expert & 12 & 11.0 & & \\
\hline & Employee trainer & 16 & 14.7 & & \\
\hline \multirow[t]{4}{*}{ Position } & Office staff & 24 & 22.0 & & \\
\hline & $\begin{array}{l}\text { General services staff (Cleaning, security } \\
\text { etc.) }\end{array}$ & 22 & 20.2 & & \\
\hline & Coach & 19 & 17.4 & & \\
\hline & $\begin{array}{l}\text { Senior manager (general manager / } \\
\text { assistant general manager / director) }\end{array}$ & 6 & 5.5 & & \\
\hline
\end{tabular}

Table 1 presents personal information of the participants. It can be inferred from the table that the average of the years worked for the organization is 5.71. Also, they work for an average of 7.89 hours daily. $56.9 \%$ of the employees have undergraduate degrees. $50.5 \%$ of them are contractual employees, $39.4 \%$ are permanent employees and $10.1 \%$ are part-time employees.

It can be inferred from the table that there are moderate negative relationships between making concessions, acting two-faced, ingratiation, forming coalitions, and exchange of favors, which are the sub-dimensions of political behavior scale, and affect-based trust and cognition-based trust, which are the sub-dimensions of trust in manager scale.

Moreover, moderate negative relationships have been found between making concessions, acting two-faced, ingratiation, forming coalitions, and exchange of favors, which are the sub-dimensions of political behavior scale, and affective commitment, which is a sub-dimension of organizational commitment scale. In addition, a low level of negative relationship has been found between continuance commitment, one of the sub-dimensions of organizational commitment, and making concessions and forming coalitions, two sub-dimensions of political behaviors.

On the other hand, a moderate positive relationship has been found between acting two-faced and ingratiation. Finally, a moderate positive relationship has been found between affect-based trust and cognition-based trust, the sub-dimensions of trust in manager scale, and affective commitment and normative commitment, which are the sub-dimensions of organizational commitment scale. 
Table 2. Correlation test results of political behavior, organizational commitment and trust in manager scales

\begin{tabular}{|c|c|c|c|c|c|c|c|c|c|c|c|c|}
\hline & & 1 & 2 & 3 & 4 & 5 & 6 & 7 & 8 & 9 & 10 & 11 \\
\hline \multirow{2}{*}{ 1- Making concessions } & $\mathrm{r}$ & 1 & & & & & & & & & & \\
\hline & $\mathrm{p}$ & & & & & & & & & & & \\
\hline \multirow{2}{*}{ 2- Acting two-faced } & $\mathrm{r}$ & $.912^{*}$ & 1 & & & & & & & & & \\
\hline & $\mathrm{p}$ & .000 & & & & & & & & & & \\
\hline \multirow{2}{*}{ 3- Ingratiation } & $\mathrm{r}$ & $.803^{*}$ & $.898^{*}$ & 1 & & & & & & & & \\
\hline & $\mathrm{p}$ & .000 & .000 & & & & & & & & & \\
\hline \multirow{2}{*}{ 4- Forming coalitions } & $\mathrm{r}$ & $.687^{*}$ & $.770^{*}$ & $.841^{*}$ & 1 & & & & & & & \\
\hline & $\mathrm{p}$ & .000 & .000 & .000 & & & & & & & & \\
\hline \multirow{2}{*}{ 5- Exchange of favors } & r & $.731^{*}$ & $.762^{*}$ & $.812^{*}$ & $.878^{*}$ & 1 & & & & & & \\
\hline & $\mathrm{p}$ & .000 & .000 & .000 & .000 & & & & & & & \\
\hline \multirow{2}{*}{ 6- Inspirational appeals } & $\mathrm{r}$ & $.635^{*}$ & $.659^{*}$ & $.696^{*}$ & $.711^{*}$ & $.767^{*}$ & 1 & & & & & \\
\hline & $\mathrm{p}$ & .000 & .000 & .000 & .000 & .000 & & & & & & \\
\hline \multirow{2}{*}{ 7- Affect-based trust } & $\mathrm{r}$ & $-.329^{*}$ & $-.329^{*}$ & $-.255^{*}$ & $-.355^{*}$ & $-.394^{*}$ & -.162 & 1 & & & & \\
\hline & $\mathrm{p}$ & .000 & .000 & .007 & .000 & .000 & .092 & & & & & \\
\hline \multirow{2}{*}{ 8- Cognition-based trust } & $\mathrm{r}$ & $-.318^{*}$ & $-.323^{*}$ & $-.219^{*}$ & $-.299^{*}$ & $-.291^{*}$ & -.103 & $.818^{*}$ & 1 & & & \\
\hline & $\mathrm{p}$ & .001 & .001 & .022 & .002 & .002 & .288 & .000 & & & & \\
\hline \multirow{2}{*}{ 9- Affective commitment } & $\mathrm{r}$ & $-.317^{*}$ & $-.326^{*}$ & $-.292^{*}$ & $-.310^{*}$ & $-.308^{*}$ & -.117 & $.432 *$ & $.514^{*}$ & 1 & & \\
\hline & $\mathrm{p}$ & .001 & .001 & .002 & .001 & .001 & .227 & .000 & .000 & & & \\
\hline Continuance & $\mathrm{r}$ & $.284^{*}$ & $.401^{*}$ & $.346^{*}$ & $.227^{*}$ & .174 & .149 & .059 & -.036 & -.141 & 1 & \\
\hline commitment & $\mathrm{p}$ & .003 & .000 & .000 & .018 & .070 & .121 & .539 & .711 & .144 & & \\
\hline \multirow{2}{*}{ 11- Normative commitment } & $\mathrm{r}$ & -.043 & .033 & .093 & .001 & -.102 & .103 & $.365^{*}$ & $.449^{*}$ & $.566^{*}$ & $.290^{*}$ & 1 \\
\hline & $\mathrm{p}$ & .653 & .731 & .336 & .989 & .290 & .287 & .000 & .000 & .000 & .002 & \\
\hline
\end{tabular}

* $\mathbf{p}<.05$

Table 3. Results of Multiple Regression Analysis of Affective Commitment Scale

\begin{tabular}{lccccccc}
\hline & $\mathbf{B}$ & Std. Er. & $\boldsymbol{\beta}$ & $\mathbf{t}$ & Sig. & Zero-Order & Partial \\
\hline Constant & 2.368 & .321 & & 7.375 & .000 & & \\
Affect-based trust & -.030 & .092 & -.051 & -.333 & .740 & .432 & -.033 \\
Cognition-based trust & .325 & .103 & .469 & 3.159 & $\mathbf{. 0 0 2}$ & .514 & .301 \\
Making concessions & -.059 & .151 & -.082 & -.391 & .696 & -.317 & -.039 \\
Acting two-faced & .019 & .202 & .027 & .095 & .925 & -.326 & .009 \\
Ingratiation & -.084 & .140 & -.140 & -.600 & .550 & -.292 & -.060 \\
Forming coalitions & -.024 & .118 & -.041 & -.206 & .837 & -.310 & -.021 \\
Exchange of favors & -.096 & .124 & -.161 & -.771 & .442 & -.308 & -.077 \\
Inspirational appeals & .127 & .083 & .208 & 1.527 & .130 & -.117 & .151 \\
\hline
\end{tabular}

$\mathrm{R}^{2}=0.316$

$\mathrm{F}_{(8-100)}=5.767 . \quad \mathrm{p}<0.000$

The results of the regression analysis of the affective commitment sub-dimension of the political behavior scale and the trust in manager scale are given in Table 3. There is a high level of significant relationship $\left(R=0.562, R^{2}=0.316, p<000\right)$ between sub-dimensions of the political behavior scale and trust in manager scale and normative commitment sub-dimension. The sub-dimensions of the political behavior scale and trust in manager scale presented in Table 3 , together, accounts for $32 \%$ of the total variance of the affective commitment sub-dimension.

The relative significance order of predictive variables on affective commitment according to standardized regression coefficient $(\boldsymbol{\beta})$ is cognition-based trust, inspirational appeals, exchange of favors, ingratiation, making concessions, affect-based trust, forming coalitions, and acting two-faced.

According to the t-test results for the significance of the regression coefficients, only the cognition-based trust sub-dimension is a significant predictor of affective commitment.

Table 4. The Results of Multiple Regression Analysis of the Continuance Commitment subscale

\begin{tabular}{|c|c|c|c|c|c|c|c|}
\hline & B & Std. Error & Beta & $\mathbf{t}$ & Sig. & Zero-order & Partial \\
\hline Constant & 2.415 & .305 & - & 7.930 & .000 & - & - \\
\hline Affect-based trust & .163 & .087 & .297 & 1.881 & .063 & .059 & .185 \\
\hline Cognition-based trust & -.088 & .097 & -.138 & -.901 & .370 & -.036 & -.090 \\
\hline Making concessions & -.266 & .143 & -.404 & -1.860 & .066 & .284 & -.183 \\
\hline Acting two-faced & .642 & .192 & .968 & 3.344 & .001 & .401 & .317 \\
\hline Ingratiation & .030 & .132 & .055 & .230 & .819 & .346 & .023 \\
\hline Forming coalitions & -.027 & .112 & -.049 & -.237 & .813 & .227 & -.024 \\
\hline Exchange of favors & -.050 & .118 & -.093 & -.428 & .669 & .174 & -.043 \\
\hline Inspirational appeals & -.073 & .079 & -.131 & -.926 & .357 & .149 & -.092 \\
\hline
\end{tabular}


The results of the regression analysis of continuance commitment sub-dimension of political behavior scale and trust in manager scale are given in Table 4. There is a high level of significant relationship between sub-dimensions of the political behavior scale and trust in manager scale and normative commitment sub-dimension $\left(R=0.518, R^{2}=0.268\right.$, $\mathrm{p}<000$ ). The sub-dimensions of the political behavior scale and trust in manager scale presented in Table 4 , together, accounts for $27 \%$ of the total variance of the continuance commitment sub-dimension.

The relative significance order of predictive variables on continuance commitment according to standardized regression coefficient $(\beta)$ is acting two-faced, making concessions, affect-based trust, cognition-based trust, inspirational appeals, exchange of favors, ingratiation and forming coalitions.

According to the t-test results for the significance of the regression coefficients, only acting two-faced sub-dimension is a significant predictor of continuance commitment.

Table 5. The Results of Multiple Regression Analysis of the Normative Commitment subscale

\begin{tabular}{lccccccc}
\hline & B & Std. Error & Beta & t & Sig. & Zero-order & Partial \\
\hline Constant & 1.965 & .330 & - & 5.951 & .000 & - & - \\
Affect-based trust & -.066 & .094 & -.106 & -.704 & .483 & .365 & -.070 \\
Cognition-based trust & .373 & .106 & .518 & 3.526 & $\mathbf{. 0 0 1}$ & .449 & .333 \\
Making concessions & -.183 & .155 & -.246 & -1.182 & .240 & -.043 & -.117 \\
Acting two-faced & .238 & .208 & .316 & 1.142 & .256 & .033 & .113 \\
Ingratiation & .169 & .144 & .270 & 1.174 & .243 & .093 & .117 \\
Forming coalitions & .126 & .121 & .205 & 1.038 & .302 & .001 & .103 \\
Exchange of favors & -.396 & .128 & -.642 & -3.101 & $\mathbf{. 0 0 3}$ & -.102 & -.296 \\
Inspirational appeals & .155 & .085 & .245 & 1.814 & .073 & .103 & .179 \\
\hline
\end{tabular}

$\mathrm{R}=0.575, \quad \mathrm{R}^{2}=0.331$

$\mathrm{F}_{(8-100)}=6,187, \quad \mathrm{p}<0.000$

The results of the regression analysis of normative commitment sub-dimension of political behavior scale and trust in manager scale are given in Table 5. There is a high level of significant relationship between sub-dimensions of the political behavior scale and trust in manager scale and normative commitment sub-dimension $\left(R=0.575, R^{2}=0.331\right.$, $\mathrm{p}<.000$ ). The sub-dimensions of the political behavior scale and trust in manager scale presented in Table 5, together, accounts for $33 \%$ of the total variance of the normative commitment sub-dimension.

The relative significance order of predictive variables on normative commitment according to standardized regression coefficient ( $\boldsymbol{\beta})$ is cognition-based trust, exchange of favors, acting two-faced, ingratiation, making concessions, inspirational appeals, forming coalitions and affect-based trust. According to the t-test results for the significance of the regression coefficients, cognition-based trust and exchange of favors sub-dimensions are significant predictors of normative commitment.

\section{Discussion and Conclusion}

The results of the study show that there is a negative relationship between the sub-dimensions of the political behavior scale and the sub-dimensions of the trust in manager scale. As the values of acting two-faced, ingratiation, forming coalitions, and exchange of favors sub-dimensions increase, the values of affect-based trust and cognition-based trust, which are the sub-dimensions of trust in manager scale, decrease. Similarly, as the values of the sub-dimensions of the political behavior scale increase, the organizational commitments of the participants decrease. Therefore, we can infer from the findings that political behavior is a significant negative predictor of trust in manager and organizational commitment. We can also argue that trust in manager is an important determinant of organizational commitment.

According to the results of multiple regression analysis, the sub-dimension of cognition-based trust, one of the sub-dimensions of trust in manager scale, is an important predictor of affective commitment, which is one of the sub-dimensions of organizational commitment scale. Affective commitment is the type of commitment most desired in organizations because it is a measure of the eagerness of employees to make sacrifices for the organization they work for. An employee has many reasons for trusting his/her manager: the most important is the belief in the integrity of the manager. If an employee develops a sense of trust in his/her manager in issues such as the manager's professional approach to work, adequacy of information on business, ability to make the right decisions, dedication to work, respect that others feel for him/her and sense of trust others develop for him/her, it is expected that the employee will develop a sense of organizational commitment.

One of the statistically significant results of multiple regression analysis is that acting two-faced sub-dimension of the political behavior scale is a significant predictor of continuance commitment, which is one of the sub-dimensions of organizational commitment scale. This finding is consistent with the literature. Continuance commitment is the type of commitment that is regarded as a measure of an employee's decision to stay within the organization due to his interests such as promotion and salary. Sub-dimensions of political behavior (e.g. ingratiation, making concessions, forming 
coalitions, exchange of favors), on the other hand, can be seen as the reason behind an employee's efforts to be an accepted member of the organization and to take advantage of scarce resources. Acting two-faced, however, is not ethically acceptable. Acting two-faced in organizations causes employees to lose trust. Due to the interests of employees, hypocritical behaviors affect their commitment to the organization.

In addition, another of the results of the analysis is that, cognition-based trust, one of the sub-dimensions of trust in manager, and exchange of favors, one of the sub-dimensions of political behavior, are significant predictors of normative commitment, one of the sub-dimensions of organizational commitment. Rather than affect-based trust grounded in emotions and relations, cognition-based trust grounded in manager's behaviors are effective in normative commitment that refers to a sense of obligation that an employee feels to his/her organization. On the other hand, it can be interpreted as an expectable outcome that exchange of favors sub-dimension has no effect on affective commitment but has an effect on normative commitment, which refers to the commitment of an employee when he/she feels that he/she ought to remain in his/her organization rather than bearing the cost of working in another organization.

Examples of other studies related to the present study are as follows:

According to a study with 115 blue-collar workers working in the textile sector, ethical leadership behavior has a direct impact on cognition-based trust. Furthermore, exchange supports the direct role of justice in the impact of ethical leadership behavior on affect-based trust and selection-effect. Researchers emphasized that interaction between employees and managers is important for affect-based trust (Arslantas \& Dursun, 2008). According to the results of a study examining the effect of leader-member exchange on organizational trust, the organizational trust levels of the participants who evaluated the leader-member exchange positively were high (Aslan \& Ozata, 2009). In addition, Arslantas (2007) proved that leader-member exchange has an impact on trust in manager.

According to a study examining the effect of trust in the manager on the commitment to the manager with structural equation modeling, trust in a manager increases commitment to the manager (Ozdasli \& Yucel, 2010). According to another study examining teachers' life satisfaction and organizational trust level in schools, there is a significant and positive relationship among sensitivity to employees, trust in the manager, communication environment and openness to innovation scores of teachers' life satisfaction and organizational trust in schools (Yilmaz \& Sunbul, 2009). Another study revealed the effect of trust in the manager and psychological empowerment on organizational citizenship behavior (Arslantas, 2008). Ulker (2008) examined the effects of employees' perceptions of organizational justice on trust in managers.

In a study examining the relationship between leadership style and trust in the manager, it was found that the transformational leadership style has a significant effect on explaining trust in the manager. When the leader-member exchange was included in the model as a conditional variable, it was concluded that transformational leadership has a higher effect on the trust in the manager for the group whose leader-member exchange is above the average (Yolac, 2011).

The results of a study with 162 employees in Malaysia are as follows. There are positive and direct relationship between transformational leadership behaviors (transformational and transactional), and organizational justice (distributive, procedural, and interactional justice) and OCB with leader-member exchange (LMX), perceived organizational support (POS), and trust as the mediators (Asgari et al., 2008). According to another study, there is a positive relationship between employees' emotional intelligence and trust in the manager (Kutanis et al., 2014).

According to a study which was conducted with academicians and examined the effect of positive psychological capital on organizational political behaviors, academicians with low psychological capital tended to make concessions, engage in hypoctical behavior and mutually beneficial behaviors more than those with high psychological capital (Oruc \& Kutanis, 2015). According to the results of a study conducted with 314 participants working in a public body, participants' perceptions of organizational politics lead to a decrease in their turnover intention and neglect in the workplace (Basar \& Varoglu, 2016). According to another study conducted with teachers, there is a positive relationship between teachers' political skills and organizational opposition levels (Ugurlu \& Bostanci, 2017). In another study, effect of organizational structure on organizational politics and procedural justice was examined and a negative correlation was found between formalization and organizational politics (Cinar-Altıntas, 2007). Another study pointed out a negative relationship between healthy organizational types and political behavior (Bostanci et al., 2016).

According to another study, secondary school teachers' perceptions of organizational politics negatively predict their organizational commitment and organizational citizenship behaviors. In addition, organizational commitment has a partial mediation role between organizational politics perception and organizational citizenship behavior (Celik \& Ustuner, 2018). According to another study, participants perceive political behavior within the organization as a threat to their well-being. This study showed that the perception of organizational politics has a positive effect on turnover intention, neglect in the workplace and burnout, and a negative effect on job satisfaction and organizational identification (Basar et al., 2015). 
According to a study that examined the relationship between impression management, organizational politics and work performance the interaction of organizational politics and impression management explained a significant incremental amount of variance in supervisor ratings of employee performance. These findings demonstrated that the extent to which an individual engaged in impression management in a non-political atmosphere may have been a key component to receiving favorable performance ratings (Zivnuska et al., 2004). According to a study examining the relationship between organizational politics, work identity and organizational commitment, employees who identified primarily with their occupations were less affected by the level of perceived politics in the organization in the consideration of their commitment than were employees who identified primarily with their employing organizations or one of its units (Witt et al., 2002). The findings of a study examining the relationship among perceived organizational politics, emotional intelligence and work outcomes show that emotional intelligence directly affects perceptions of politics, and indirectly affects employees' work attitudes and behaviors, through a mediation effect of perceived politics (Meisler \& Vigado-Gadot, 2014).

In conclusion, an organization is a whole. Each part of an organization must be in harmony with another. The most important factor to ensure this harmony is healthy communication and behaviors and attitudes of managers establishing and consolidating the perception of justice. Political behaviors can be accepted to a certain extent, but as political behavior increases, organizational commitment decreases. Organizations need committed employees. In order to achieve this, they need to create an organizational culture which will increase organizational commitment, ensure trust in the manager and the organization and reduce political behaviors. It can be suggested that organizational commitment, trust in manager, and political behavior variables should be investigated together with different variables and groups. Especially, only sport sector managers the results could be different.

\section{References}

Akcakanat, T., \& Uzunbacak, H. H. (2017). Effects of proactive personality on political skills. Business \& Management Studies: An International Journal, 5(3), 786-807. [Turkish]

Akis, Y. T. (2004). Turkey 's real managerial map.Istanbul: Alfa Publication. [Turkish]

Allen, N. J., \& Meyer J. P. (1990). The measurement and antecedents of affective, continuance and normative commitment to the organization. Journal of Occupational Psychology, 63(1), 1-18. https://doi.org/10.1111/j.2044-8325.1990.tb00506.x

Arslantas, C. C. (2007). An empirical study on the effect of leader-member exchange on trust in supervisor. TISK Academy, 2(39), 161-173.

Arslantas, C. C. (2008). An empirical study on determining the effects of trust on manager and psychological empowerment on organizational citizenship behavior. TISK Academy, 1, 101-117. [Turkish]

Arslantas, C. C., \& Dursun, M. (2008). The impact of ethical leadership behavior on trust in manager and psychological empowerment: The Mediating role of interactional justice. Anadolu University Journal of Social Sciences, 8(1), 111-128. [Turkish]

Asgari, A., Silong, A. D., Ahmad, A., \& Samah, B. A. (2008). The relationship between transformational leadership behaviors, organizational justice, leader-member exchange, perceived organizational support, trust in management and organizational citizenship behaviors. European Journal of Scientific Research, 23(2), 227-242.

Aslan, H., \& Pektas, V. (2017). Political skill levels of teachers working at primary, secondary and high schools. Scientific Educational Studies, 1(1), 85-100.

Aslan, S., \& Ozata, M. (2009). Effect of leader-effect exchange (LMX) on confidence for manager. $S U$ IIBF, The Journal of Social Economic Research, 9(17), 94-116. [Turkish]

Asunakutlu, T. (2002). An evaluation of the factors related to creation of organizational trust. Mugla University, Journal of Social Sciences Institute, 9, 1-13. [Turkish]

Bagci, Z. (2013). The impacts of justice perceptions of employees on organizational commitments: an investigation in textile sector. International Journal of Management Economics and Business. 9(9):163-184.

Basar, U., \& Varoglu, A. K. (2016). Intention to quit as a mediator of the relationship between perceptions of organizational politics and neglect of work. Manisa Celal Bayar University Journal of Management and Economics, 23(3), 751-765. [Turkish]

Basar, U., Alan, H., Topcu, M. K., \& Aksoy, S. (2015). A survey on the antecedents of the perceptions of organizational policy. 3. Organizational Behavior Congress. 6-7 Kasım 2015, Tokat/ Turkey. Conference paper. [Turkish]

Basol, G., \& Yalcin, B. (2009). The reliability analysis of Meyer and Allen three-dimessions organizational commitment 
scale in the education organizations [Full Text]. 5th International Balkan Educational and Science Congress Full Text Book, 2, 497- 507, Trakya University, Edirne, Turkey. [Turkish]

Bell, M., P., \& James, C. (2002). Quick and cynthia s. cycyota, "assessment and preventation of sexual harassment of employees: an applied guide to 119 creating healthy organizations", International Journal of Selection and Assessment, 10(1/2), 160-167. https://doi.org/10.1111/1468-2389.00203

Bijlsma, K. M., \& Van de Bunt, G. G. (2003). Antecedents of trust in managers: a "bottomup" approach. Personnel Review, 32(5), 638-664. https://doi.org/10.1108/00483480310488388

Bokeoglu, O. C., \& Yilmaz, K. (2008). Teachers' perceptions about the organizational trust in primary school. Educational Administration: Theory and Practice, 14, 2, 211-233. [Turkish]

Bostanci, A. B., Akcadag, T., Kahraman, U., \& Tosun, A. (2016). The relationship between schools' DNA profiles and political behavior in school. Journal of Human Sciences, 13(3), 5693-5705. https://doi.org/10.14687/jhs.v13i3.4307

Boyaci, M. F. (2010). Effective communication, enhancing the organizational commitment: an application. Master Thesis. Ankara: Gazi University. [Turkish]

Brown, B. B. (2003). Employees' organizational commitment and their perception of supervisors' relations-oriented and task-oriented leadership behaviors. Doctoral dissertation, State University, Dissertation Abstracts International.

Celik, O. T., \& Ustuner, M. (2018). The relationship between secondary school teachers' perceptions of organizational politics and their organizational commitment and organizational citizenship behaviors. H. U. Journal of Education, 1-12. https://doi.org/10.16986/HUJE.2018044109

Cinar-Altintas, F. (2007). Analysing effect of organizational structure on organizational politics and procedural justice with structural equation modelling. Anadolu University Journal of Social Sciences, 7(2), 151-168. [Turkish]

Coban, N. (2007). The organizational health perception of the primary schools' administrators and teachers (Antalya case). Master Thesis. Akdeniz University, Social Sciences Institute, Antalya. [Turkish]

Deluga, R. J. (1994). Supervisor trust building, leader-member exchange and organizational citizenship behaviors. Journal of Occupational and Organizational Psychology, 67, 315-326. https://doi.org/10.1111/j.2044-8325.1994.tb00570.x

Demirel, Y. (2008). The Impact of organizational trust on organizational commitment: A Study of employees in the textile industry. Manisa Celal Bayar University Journal of Management and Economics, 15(2), 181-194. [Turkish]

Eroglu, E. (2011). Evaluation of the factors which affect the communication quality in organizations. Selcuk University, The Journal of Institute of Social Sciences, 26, 137-149. [Turkish]

Eryilmaz, I., \& Gulova, A. A. (2017). The Effect of organizational climate on perceived organizational politics: A Research in public sector. Manisa Celal Bayar University, Journal of Social Sciences, 15(4), 155-176. [Turkish]

Geri, S. (2010). The effect of the leadership styles on organizational commitment (Directorate of Youth and Sports). Doctorate Thesis. İstanbul: Marmara University. [Turkish]

Gulova, A. A., \& Demirsoy, O. (2012). The relationship between organizational culture and organizational commitment: an empirical research on employees of service sector. Business and Economic Research Journal, 3(3), 49-76.

Gundogan, T. (2009). Organizational commitment: apply the central bank of the republic of Turkey. Expertise proficiency thesis. Ankara. [Turkish]

Hubbell, A. P., \& Chory-Assad R. M. (2005). Motivating factors: perceptions of justice and their relationship with managerial and organizational trust. Communication Studies, 56(1), 47-70. https://doi.org/10.1080/0008957042000332241

Ibicioglu, H. (2000). The place of paradigmatic adaptation in organizational commitment. Dokuz Eylul University Faculty of Economics and Administrative Sciences, 15(1), 13-22. [Turkish]

Ince, M. (2005). The phenomenon of change and the changing functions of human resources management in. Journal of Social Sciences Institute of Selcuk University. 14:319-339. [Turkish]

Ince, M., \& Gul, H. (2005). A New Paradigm in Management: Organizational Commitment. Koyya: Cizgi Publishing.

Islamoglu, G., \& Boru, D. (2007). Scale development for the dimensions of political behaviour. Akdeniz University Faculty of Economics and Administrative Sciences, 7(14), 135-153. [Turkish]

Koc, H. (2009). The Relation between organizational commitment and loyalty. Electronic Journal of Social Sciences, 
8(28), 200-211. [Turkish]

Krot, K., \& Lewicka, D. (2012). The importance of trust in manager-employee relationships. International Journal of Electronic Business Management, 10(3), 224-233.

Kul, M., \& Guclu, M. (2010). The relationship between school administrators' leadership style and physical education teachers' organizational commitment. International Journal of Human Sciences, 7(2), 1021-1038. [Turkish]

Kutanis, O. R., Ardic, K., Uslu, O., \& Karakiraz, A. (2014). Emotional intelligence, fear based silence and trust to manager: a case study. Polish Journal of Management Studies, 10(2), 133-142.

Mayer, R. C., Davis, J. H., \& Schoorman, F. D. (1995). An integrative model of organizational trust. Academy of Management Review, 20(3), 709-734. https://doi.org/10.5465/amr.1995.9508080335

McAllister, D. J. (1995). Affect and cognition based trust as foundations for interpersonal cooperation in organizations. Academy of Management Journal, 38(1), 24-59.

Meisler, G., \& Vigado-Gadot, E. (2014). Perceived organizational politics, emotional intelligence and work outcomes: Empirical exploration of direct and indirect effects. Personnel Review, 43(1), 116-135. https://doi.org/10.1108/PR-02-2012-0040

Meyer, J. P., \& Allen, N. J. (1997). Commitment in the workplace-theory, research and application. USA: Sage Publications.

Meyer, J. P., \& Allen, N. J. A. (1991). Three-component conceptualization of organizational commitment. Human Resources Management Review, 1, 61-89. https://doi.org/10.1016/1053-4822(91)90011-Z

Odemis, S. (2011). The effect of five factor personality traits on counter-productive behaviours: An emprical study. Doctorate Thesis, Marmara University, Social Sciences Institute, Istanbul. [Turkish]

Oruc, E. (2015). The impact of positive psychological capital on political behaviour: A study on academic staff. Doctorate Thesis, Sakarya University, Social Sciences Institute, Sakarya. [Turkish]

Oruc, E., \& Kutanis, O. R. (2015). The Impact of positive psychological capital on political behaviour in organizations: a study on academic staff. The Journal of Business Research, 7(3), 36-58. [Turkish]

Ozdasli, K., \& Yucel, S. (2010). The effect of trusting to manager to commitment to manager an analysis with structural equity model. Journal of Suleyman Demirel University Institute of Social Sciences, 1(11), 67-83. [Turkish]

Ozturk, C., \& Aydin, B. (2012). High school teachers' perceptions of trust in organization. Gaziantep University Journal of Social Sciences, 1(2), 485-504. [Turkish]

Saglam-Ari, G. (2003). The relation of trust and empowerment in organizations: A research in banking. Doctorate Thesis, Hacettepe University, Social Sciences Institute. Ankara. [Turkish]

Saglam-Ari, G., \& Tuncay, A. (2010). The relationship between trust and burnout: A research on the administrative staff employees in state hospitals in Ankara. Journal of Economics and Administrative Sciences. 24(4), 113-135. [Turkish]

Sahin, M. (2017). The examination of personals conflict and constraintssituations and their work behaviors against productivitiy. Master Thesis. Ataturk University, Social Sciences Institute, Erzurum, Turkey [Turkish]

Teyfur, M., Beytekin O. F., \& Yalcinkaya, M. (2013). A Research on the ethical leadership of primary school administrators and the organizational trust levels in primary schools: The Sample of Izmir. Dicle University Journal of Ziya Gokalp Faculty of Education, 21(2013), 84-106. [Turkish]

Turgut, H. S. (2016). Intermediary roles between personal traits, trust to the manager and burnout in banking sector. Master Thesis. Arel Universty, Social Sciences Institute. Department of Psychology. [Turkish]

Tutar, H. (2007). A case study of procedural justice, job satisfaction, and emotional commitment of medical personnel in public and private hospitals in Erzurum. Suleyman Demirel University, The Journal of Faculty of Economics and Administrative Sciences, 12(3), 97-120. [Turkish]

Ugurlu, E., \& Bostanci, A. B. (2017). The relationship between teachers' political skills and organizational opposition levels. Journal of Human Sciences, 14(4), 4050-4064. [Turkish] https://doi.org/10.14687/jhs.v14i4.5070

Ulker, G. (2008). The effects of organizational justice perception of employees on manager and executive. Abant Izzet Baysal University, Graduate School of Social Sciences Journal of Social Sciences, 1,16, 188-208. [Turkish]

Uslu, O., \& Ardic, K. (2013). Does power distance effect organizational trust? Afyon Kocatepe University, Journal of Economics and Administrative Sciences, XV(II) 313-338.[Turkish] 
Vigoda, E. (2000). Organizational politics, job attitudes, and work outcomes: exploration and implications for the public sector. Journal of Vocational Behavior, 57(3), 326-347. https://doi.org/10.1006/jvbe.1999.1742

Vigoda-Gadot, E. (2007). Leadership style, organizational politics, and employees' performance: an empirical examination of two competing models. Personnel Review, 36(5), 661-683. https://doi.org/10.1108/00483480710773981

Vigoda-Gadot, E., Vinarski-Peretz, H., \& E. Ben-Zion, E. (2003). Politics and image in the organizational landscape: an empirical examination among public sector employees. Journal of Managerial Psychology, 18(8), 764-787. https://doi.org/10.1108/02683940310511872

Wasti, A. (2009). Focus, antecedents and outcomes of Organizational Commitment. In: Keser A, Yilmaz G, Yurur S. (ed). Behavior in Work Life: Current Approaches. 1. Edition. Kocaeli:Umuttepe Publishing, 16-38.

Wasti, S. A. (2000). The reliability and validity analysis of Allen\&Meyer three-dimensions organizational commitment scale. 8. National Management and Organization Congress Papers, 401-410.

Witt, L. A., Patti, A. L., \& Farmer, W. L. (2002). Organizational politics and work identity as predictors of organizational commitment. Journal of Applied Social Psychology, 32(3), 486-499. https://doi.org/10.1111/j.1559-1816.2002.tb00226.x

Yilmaz, E. (2009). Examining organizational commitment of primary school teachers regarding to their job satisfaction and their school's organizational creativity. Elementary Education Online ,8(2), 476-484. [Turkish]

Y1lmaz, E., \& Sunbul, A. M. (2009). The organizational confidence level in school and saturation of the life of teacher. Journal of Kafkas University, 26,172-179. [Turkish]

Yolac, S. (2011). The Role of the leader- member interaction in the relationship between the perceived leadership style and the trust in manager. Journal of Oneri, 9(36), 63-72. [Turkish]

Yuksel, M., \& Bolat, T. (2016). The relationships between organizational politics, hofstede's organizational cultural dimensions, job attitude and job outcomes. Eskisehir Osmangazi University Journal of Economics and Administrative Sciences, 11(3), 173-204. [Turkish]

Zivnuska, S., Kacmar, K. M., Witt, L. A., Carlson, D. S., \& Bratton, V. K. (2004). Interactive effects of impression management and organizational politics on job performance. Journal of Organizational Behavior, 25(5), 627-640. https://doi.org/10.1002/job.262

\section{Copyrights}

Copyright for this article is retained by the author(s), with first publication rights granted to the journal.

This is an open-access article distributed under the terms and conditions of the Creative Commons Attribution license which permits unrestricted use, distribution, and reproduction in any medium, provided the original work is properly cited. 